\title{
Mixtures of recombinant growth factors inhibit the production of pro-inflammatory mediators and cytokines in LPS-stimulated RAW 264.7 cells by inactivating the ERK and NF-кB pathways
}

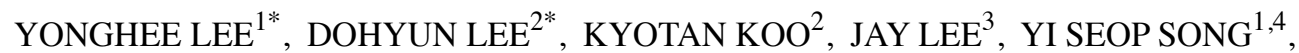 \\ HO SANG YOON ${ }^{5}$, YOO MI CHOI ${ }^{6}$ and BEOM JOON KIM ${ }^{1,4}$ \\ ${ }^{1}$ Department of Dermatology, Chung-Ang University College of Medicine; ${ }^{2}$ Nutrex Technology R\&D Center, \\ ${ }^{3}$ Marketing and Business Division, PacificPharma Corporation; ${ }^{4}$ Department of Medicine, The Graduate School, \\ Chung-Ang University, ${ }^{5} \mathrm{MB}$ Business Development Team and ${ }^{6}$ Cosmeceutical Team, \\ PacificPharma Corporation, Seoul, Republic of Korea
}

Received January 3, 2014; Accepted May 13, 2014

DOI: $10.3892 /$ ijmm.2014.1790

\begin{abstract}
Growth factors are important for regulating a variety of cellular processes and typically act as signaling molecules between cells. In the present study, we examined the mechanisms underlying the inhibitory effects of mixtures of recombinant growth factors (MRGFs) on nitric oxide (NO) and pro-inflammatory cytokine production in lipopolysaccharide (LPS)-stimulated RAW 264.7 cells. We also examined whether these effects are mediated through the mitogen-activated protein kinase (MAPK) and nuclear factor $-\kappa \mathrm{B}(\mathrm{NF}-\kappa \mathrm{B})$ signal transduction pathways. NO production was assessed by measuring nitrite acucmulation using the Greiss reaction. Cytokine concentrations were measured using respective ELISA kits for each cytokine. Our results revealed that the MRGFs significantly attenuated the LPS-induced production of pro-inflammatory cytokines and NO in a dose-dependent manner. To elucidate the mechanisms underlying the inhibitory effects of MRGFs, we examined the effects of the LPS-induced phosphorylation of MAPKs and the activation of the NF- $\kappa \mathrm{B}$ signaling pathway on the stabilization of NF- $\kappa \mathrm{B}$ nuclear translocation and inhibitory factor- $\kappa \mathrm{B}(\mathrm{I} \kappa \mathrm{B})$ degradation. Western blot analysis was performed to determine the total and phosphorylated levels of ERK, as well as the nuclear translocation of $\mathrm{NF}-\kappa \mathrm{B}$, and I $\mathrm{B}$ phosphorylation and degradation. Our results demonstrated that treatment with
\end{abstract}

Correspondence to: Professor Beom Joon Kim, Department of Dermatology, Chung Ang University College of Medicine, 224-1 Heukseok-dong, Dongjak-ku, Seoul 156-755, Republic of Korea E-mail: beomjoon@unitel.co.kr

${ }^{*}$ Contributed equally

Abbreviations: NO, nitric oxide; MRGFs, mixtures of recombinant growth factors; MAPK, mitogen-activated protein kinase; LPS, lipopolysaccharide; NF- $\kappa \mathrm{B}$, nuclear factor- $\kappa \mathrm{B}$; I $\mathrm{B}$, inhibitory factor- $\kappa \mathrm{B}$

Key words: growth factor, RAW 264.7 cells, inflammation, mitogenactivated protein kinase, nuclear factor- $\kappa \mathrm{B}$
MRGFs resulted in a reduction in the phosphorylation of the ERK and NF- $\kappa \mathrm{B}$ signaling pathways, whereas the phosphorylation of JNK and p38 was not affected. Taken together, our results suggest that MRGFs inhibit the production of pro-inflammatory cytokines and NO by downregulating inducible NO synthase gene expression and blocking the phosphorylation of the ERK and $N F-\kappa B$ signaling pathways. These findings may provide direct evidence of the potential application of MRGFs in the prevention and treatment of inflammatory diseases.

\section{Introductions}

Various growth factors, also known as cytokines or steroid hormones, regulate a variety of cellular processes, as well as the development of tumors, inflammation and wound healing. These growth factors differ from well-known polypeptide hormones, such as insulin and adrenocorticotropic hormone, not only in the response elicited, but also in the mode of delivery from the secreting to the responding cell. Growth factors also have different cell-type specificities and different functions (1-4). For example, epidermal growth factor (EGF), basic fibroblast growth factor (bFGF) and keratinocyte growth factor (KGF) are thought to play a role in wound healing and the regulation of class II major histocompatibility complex, macrophages and lymphocytes. During this process, inflammation initiates healing. The regulation of inflammation is so important that homeostatic mechanisms have evolved to control this process (1,5-9). Insulin-like growth factor (IGF)-1 displays pleiotropic properties, including the ability to promote cellular proliferation and differentiation, as well as processes involved in metabolism/hypertrophy, such as nutrient transport, energy storage, gene transcription and protein synthesis (10). Superoxide dismutase (SOD), one of the most important antioxidants, is an enzyme that catalyzes the dismutation of superoxide $\left(\mathrm{O}_{2}^{-}\right)$into oxygen and hydrogen peroxide and serves as a key antioxidant in cells (11). The aforementioned growth factors, including EGF, bFGF, KGF, IGF-1 and SOD, act by binding to their respective receptor tyrosine kinases, followed by the downstream signaling and activation of the protein 
kinase C, AKT and ERK signaling pathways. In particular, mitogen-activated protein kinase (MAPK) signaling, including ERK, plays a critical role in innate immune responses $(8,11,12)$.

MAPKs are serine/threonine-specific protein kinases (13-16). They are important upstream factors that lead to the activation of nuclear factor- $\kappa \mathrm{B}(\mathrm{NF}-\kappa \mathrm{B})(6,17)$. They are mainly composed of three subfamily members: ERK, JNK and p38. The MAPK signaling pathway regulates a wide variety of cellular events, including complex cellular programs, such as differentiation, proliferation, apoptosis and processes involved in immune response (18). The phosphorylation of MAPKs modulates the expression of a variety of genes involved in immune and inflammatory responses, including inducible nitric oxide (NO) synthase (iNOS) and cyclooxygenase-2 (COX-2).

In addition, $\mathrm{NF}-\kappa \mathrm{B}$ nuclear translocation, as well as inhibitory factor- $\kappa \mathrm{B}(\mathrm{I} \kappa \mathrm{B})$ phosphorylation and degradation are important inflammatory factors. The expression of proinflammatory cytokines is mainly regulated by the $\mathrm{NF}-\kappa \mathrm{B}$ pathway (19). In unstimulated cells, $N F-\kappa B$ resides in the cytoplasm as an inactive NF- $\kappa \mathrm{B}-\mathrm{I} \kappa \mathrm{B}$ complex (20).

Although there are several studies focusing on the growth factors and pathways associated with inflammation $(8,12,21)$, the mechanisms underlying the inflammatory response, particularly the response to a mixture of the five aforementioned growth factors, have not been investigated to date.

In this study, the anti-inflammatory effects of mixtures of recombinant growth factors (MRGFs) on the generation of several chemokines, cytokines and enzymes involved in the inflammatory process, such as inducible iNOS, COX-2, interleukin (IL)-1 $\beta$, IL-6, IL-10, IL-12p40, granulocyte-macrophage colony-stimulating factor (GM-CSF), monocyte chemoattractant protein-1 (MCP-1), tumor necrosis factor- $\alpha$ (TNF- $\alpha$ ) and NO in lipopolysaccharide (LPS)-stimulated RAW 264.7 cells, were investigated. We also investigated whether MRGFs affect the LPS-stimulated ERK and NF- $\mathrm{BB}$ signaling pathways.

\section{Materials and methods}

Materials. Mixed in the same ratio, recombinant human EGF, recombinant human bFGF, recombinant human KGF, recombinant human IGF-1 and recombinant human SOD were provided by Nutrex Technology Co., Ltd. (Seoul, Korea). 3-(4,5-Dimethylthiazol-2-yl)-2,5-diphenyltetrazolium bromide (MTT) and LPS were purchased from Sigma Chemical Co. (St. Louis, MO, USA); Dulbecco's modified Eagle's medium (DMEM), fetal calf serum (FBS), trypsin EDTA, phosphatebuffered saline (PBS) and penicillin/streptomycin were purchased from WelGENE Co. (Daegu, Korea). Antibodies specific to COX-2, and GAPDH were purchased from Santa Cruz Biotechnology, Inc. (Santa Cruz, CA, USA); iNOS was purchased from Pharmingen BD Biosciences (San Diego CA, USA). Antibodies against phosphorylated (p-)ERK, ERK, p-JNK, JNK, p-p38, p38, NF- $\mathrm{B}, \mathrm{p}-\mathrm{I} \kappa \mathrm{B}, \mathrm{I} \kappa \mathrm{B}$ and lamin $\mathrm{B} 1$ were purchased from Cell Signaling Technology (Berverly, MA, USA). PD98059 and IKK inhibitor VII were purchased from Sigma Chemical Co. and Calbiochem (San Diego, USA), respectively. The secondary antibodies, anti-goat IgG, anti-mouse IgG and anti-rabbit IgG were purchased from Vector Laboratories (Burlingame, CA, USA). The iNOS, COX-2 and GAPDH oligonucleotide primers were obtained from Bioneer, Inc. (Seoul, Korea).
Culture of RAW 264.7 cells. The RAW 264.7 murine macrophage cells were maintained at $37^{\circ} \mathrm{C}$ in a humidified atmosphere of $95 \%$ air and $5 \% \mathrm{CO}_{2}$ in DMEM supplemented with $10 \%$ heat-inactivated fetal bovine serum, $100 \mathrm{U} / \mathrm{ml}$ penicillin and $10 \mu \mathrm{g} / \mathrm{ml}$ streptomycin.

Cell viability. Cell viability was assessed by MTT assay that was performed using a slightly modified version of the method described in the study by Twentyman and Luscombe (22). Seeded RAW 264.7 cells in a 12-well plate were treated with LPS and MRGFs after $24 \mathrm{~h}$ of incubation. The supernatant was removed and MTT solution was added to each well followed by further incubation for $4 \mathrm{~h}$. Subsequently, $1.5 \mathrm{ml}$ of dimethyl sulfoxide (DMSO) were added to each well to solubilize any deposited formazon. Following incubation for $10 \mathrm{~min}$ at room temperature, the optical density (OD) was determined at $540 \mathrm{~nm}$ on an ELISA plate reader (Thermomax, Molecular Devices, Sunnyvale, CA, USA).

NO assay. NO production was assessed by measuring nitrite accumulation. After the RAW 264.7 cells were seeded in a 12-well plate, LPS $(100 \mathrm{ng} / \mathrm{ml})$ and MRGFs at the indicated concentrations $(0.01,0.1,1$ and $10 \mu \mathrm{g} / \mathrm{ml})$ were added to the culture medium, followed by incubation for $24 \mathrm{~h}$. Cells treated with LPS only were used as controls. The concentration of nitrite in the spent culture medium was determined using the Griess reaction. Subsequently, $100 \mu 1$ of supernatant from each well were transferred to a 96-well plate and mixed with $100 \mu \mathrm{l}$ of Griess reagent (Thermo Fisher Scientific, Wilmington, DE, USA) in a separate 96-well plate. Following incubation for $10 \mathrm{~min}$ at room temperature, OD was determined at $540 \mathrm{~nm}$ on an ELISA plate reader.

Cell lysate preparation and western blot analysis. Treated whole cell extracts were lysed in RIPA buffer containing $50 \mathrm{mM}$ Tris (pH 7.4), $150 \mathrm{mM} \mathrm{NaCl}, 0.5 \%$ Triton X-100, $0.1 \%$ sodium dodecyl sulfate (SDS) (Sigma Chemical Co.) and a protease inhibitor cocktail tablet (Roche Diagnostics, Indianapolis, IN, USA) for the preparation of cellular extracts. Cytoplasmic and nuclear proteins were extracted using buffer $\mathrm{A}$ [HEPES $10 \mathrm{mmol} / \mathrm{l}, \mathrm{pH}$ 7.9, $\mathrm{KCl} 10 \mathrm{mmol} / 1,2 \mathrm{mM}$ EDTA, phenylmethylsulfonyl fluoride (PMSF) $1 \mathrm{mmol} / 1,1 \mathrm{mM}$ EGTA, dithiothreitol (DTT) $1 \mathrm{mmol} / \mathrm{l}$, aprotinin $1 \mathrm{mg} / \mathrm{l}$ and protease inhibitor cocktail tablet $5 \mathrm{mg} / \mathrm{ml}$ ] and buffer B (HEPES $20 \mathrm{mmol} / 1, \mathrm{pH} 7.9, \mathrm{NaCl} 420 \mathrm{mmol} / 1$, edetic acid $0.1 \mathrm{mmol} / 1$, egatazic acid $0.1 \mathrm{mmol} / 1$, PMSF $1 \mathrm{mmol} / 1$, DTT $1 \mathrm{mmol} / 1$, aprotinin $1 \mathrm{mg} / \mathrm{l}$ and protease inhibitor cocktail tablet $1 \mathrm{mg} /$ $\mathrm{ml}$ ), as previously described (23). The protein concentration of the extracts was estimated using Bradford reagent (Bio-Rad Laboratories, Inc., Hercules, CA, USA) with bovine serum albumin as the standard, as previously described (24).

For western blot analysis, cell lysates containing $20 \mu \mathrm{g}$ of proteins were resolved by $10-12 \%$ sodium dodecyl sulfatepolyacrylamide gel electrophoresis, and transferred onto polyvinylidene fluoride (PVDF) membranes. The membranes were washed with Tris-buffered saline (10 mM Tris, $150 \mathrm{mM}$ $\mathrm{NaCl}$ ) containing $0.05 \%$ Tween-20 (TBST) and blocked in TBST containing 5\% non-fat dried milk. The membranes were further incubated with respective specific antibodies. The membranes were continuously incubated with appropriate 
secondary antibodies coupled to horseradish peroxidase and developed using enhanced chemiluminescence (ECL) western blotting detection reagents (Amersham Pharmacia Biotech, Piscataway, NJ, USA).

Reverse transcription-polymerase chain reaction (RT-PCR). Total RNA was extracted using TRIzol reagent (Invitrogen, Carlsbad, CA, USA) according to the manufacturer's instructions following treatment and quantified using an ND-1000 spectrophotometer (Thermo Fisher Scientific) with a ratio of absorbance at $260 \mathrm{~nm}$. cDNA was synthesized with $2 \mu \mathrm{g}$ of denatured total RNA in a final volume of $20 \mu \mathrm{l}$ of buffer containing $\mathrm{MgCl}_{2}, \mathrm{KCl}$, dNTPs and oligo(dT) reverse transcriptase by incubation at $42^{\circ} \mathrm{C}$ for $60 \mathrm{~min}$. The cDNA obtained was amplified with the following primers: iNOS forward, 5'-CTA CCT ACC TGG GGA ACA CCT GGG-3' and reverse, 5'-GGA GGA GCT GAT GGA GTA GTA GCG G-3'; COX-2 forward, 5'-CTG TAT CCC GCC CTG CTG GTG-3' and reverse, 5'-ACT TGC GTT GAT GGT GGC TGT CTT-3'; and GAPDH forward, 5'-GCC AAA AGG GTC ATC ATC TC-3' and reverse, 5'-GGT CCT CAG TGT AGC CCA AG-3'. Application was performed using PCR Master Mix (Takara Bio Inc., Shiga, Japan) in a total volume $20 \mu \mathrm{l}$. PCR cycling conditions consisted of denaturation at $94^{\circ} \mathrm{C}$ for $30 \mathrm{sec}$, annealing at $60^{\circ} \mathrm{C}$ for $1 \mathrm{~min}$ and extension at $72^{\circ} \mathrm{C}$ for $30 \mathrm{sec}$. The products were electrophoresed for $30 \mathrm{~min}$ at $100 \mathrm{~V}$ on a $1 \%$ agarose gel. Gels were visualized using the Molecular Imager ${ }^{\circledR}$ Gel Doc ${ }^{\mathrm{TM}}$ XR imaging system (Bio-Rad Laboratories, Inc.).

Real-time PCR. Total RNA and the cDNAs were generated as described above. Real-time PCR was performed with a C1000 ${ }^{\mathrm{TM}}$ Thermal Cycler (Bio-Rad Laboratories, Inc.) using SYBR-Green (Takara Bio Inc.). Reactive mixtures were incubated for 40 cycles at $95^{\circ} \mathrm{C}$ for $15 \mathrm{sec}, 58^{\circ} \mathrm{C}$ for $45 \mathrm{sec}$ and $72^{\circ} \mathrm{C}$ for $20 \mathrm{sec}$. Gene expression was normalized to those of the housekeeping gene, GAPDH.

ELISA for the detection of cytokine production. After the RAW 264.7 cells were seeded in a 24-well plate, LPS and MRGFs were added to each well and followed by incubation for $24 \mathrm{~h}$. The cytokine concentrations in the culture medium were measured using the ELISA kit for each cytokine (eBioscience, San Diego, CA, USA).

Statistical analysis. Statistical analyses were performed using SPSS version 18.0 for Windows (SPSS Inc., Chicago, IL, USA). Results are expressed as the means \pm standard deviation, as previously described (25). Data were analyzed using one-way ANOVA followed by a Duncan's test for multiple comparison; a two-tailed value of $\mathrm{P}<0.05$ was considered to indicate a statistically significant difference.

\section{Results}

Effect of MRGFs on cell viability and NO production. After examining the effects of each of the five growth factors (EGF, bFGF, KGF, IGF-I and SOD) on NO production and cell viability, we examined the effects of MRGFs on the production of NO. As none of the five growth factors decreased cell viability or NO production up to a concentration of $100 \mathrm{ng} / \mathrm{ml}$ in the

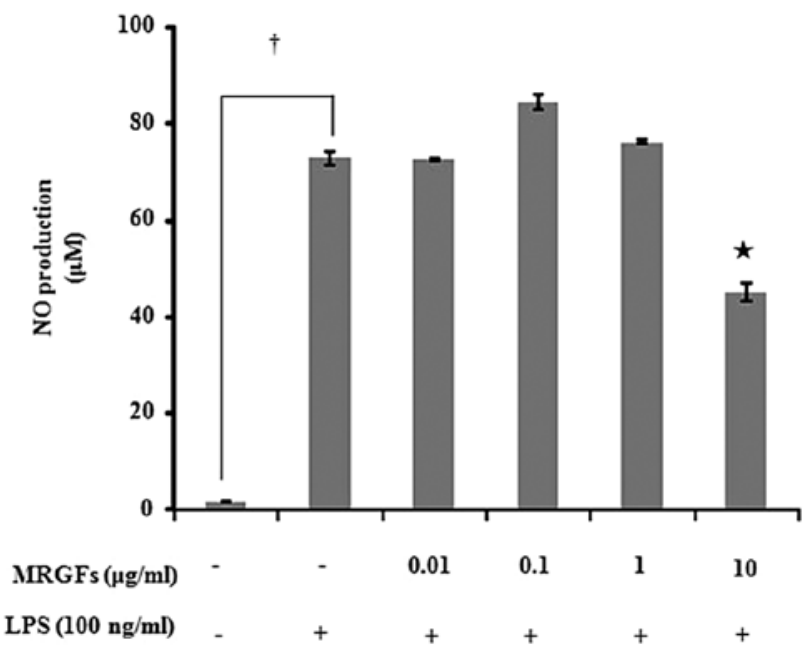

Figure 1. Inhibition of nitric oxide (NO) production by mixtures of recombinant growth factors (MRGFs) in lipopolysaccharide (LPS)-stimulated RAW 264.7 cells. After the RAW 264.7 cells were incubated for $24 \mathrm{~h}$ in 12 -well plates, they were co-treated with various concentrations of MRGFs $(0$, $0.01,0.1,1$ and $10 \mu \mathrm{g} / \mathrm{ml}$ ) and $100 \mathrm{ng} / \mathrm{ml}$ LPS for $24 \mathrm{~h}$. The nitrite concentration in the culture medium was determined using the Griess reaction method. Data are expressed as the means \pm standard deviation $(\mathrm{SD})(\mathrm{n}=3)$. Data are the means $\pm \mathrm{SD}(\mathrm{n}=3)$. ${ }^{\dagger} \mathrm{P}<0.05$ vs. control; ${ }^{*} \mathrm{P}<0.05$ vs. LPS-stimulated.

LPS-stimulated RAW 264.7 cells (data not shown), we prepared MRGFs by mixing $100 \mathrm{ng} / \mathrm{ml}$ of each of the five growth factors in the same ratio. As the MRGFs did not decrease the viability of the RAW 264.7 cells up to a concentration of $10 \mu \mathrm{g} / \mathrm{ml}$ (data not shown), this concentration was used in the subsequent experiments. The RAW 264.7 cells were incubated with LPS $(100 \mathrm{ng} / \mathrm{ml})$ and MRGFs at concentrations of $0.01,0.1,1$ and $10 \mu \mathrm{g} / \mathrm{ml}$ for $24 \mathrm{~h}$, and the NO production was measured. The levels of NO production following treatment of the RAW264.7 cells with the MRGFs are shown in Fig. 1. Following treatment with $10 \mu \mathrm{g} / \mathrm{ml}$ of MRGFs, NO production significantly decreased in the RAW 264.7 cells compared to the LPS-stimulated control $(\mathrm{P}<0.05)$. These results demonstrate that MRGFs inhibit the production of NO by suppressing iNOS activity.

Inhibitory effects of MRGFs on iNOS and COX-2 protein and mRNA expression in LPS-stimulated RAW 264.7 cells. We investigated the effects of MRGFs on LPS-stimulated iNOS and COX-2 protein expression by western blot analysis and mRNA expression by RT-PCR and real-time PCR. After the cells were co-treated with LPS $(100 \mathrm{ng} / \mathrm{ml})$ and MRGFs at a concentration of $0.01,0.1,1$ and $10 \mu \mathrm{g} / \mathrm{ml}$ for 24 and $6 \mathrm{~h}$, we harvested the protein and mRNA samples. MRGFs at a concentration of $10 \mu \mathrm{g} / \mathrm{ml}$ significantly decreased iNOS and COX-2 protein and mRNA expression in the LPS-stimulated cells (Fig. 2). Therefore, the MRGFs showed a significant inhibitory effect on the production of pro-inflammatory mediators, such as iNOS and COX-2 in the LPS-stimulated RAW 264.7 cells.

Inhibitory effects of MRGFs on MAPK phosphorylation in LPS-stimulated RAW 264.7 cells. We examined the effects of MRGFs on LPS-stimulated MAPK phosphorylation in the RAW 264.7 cells. After the cells were stimulated with LPS, western blot analysis was performed to determine the total and 
$\mathbf{A}$

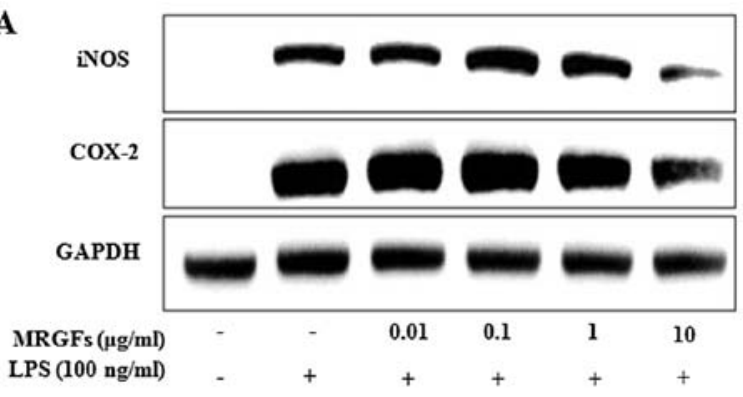

B

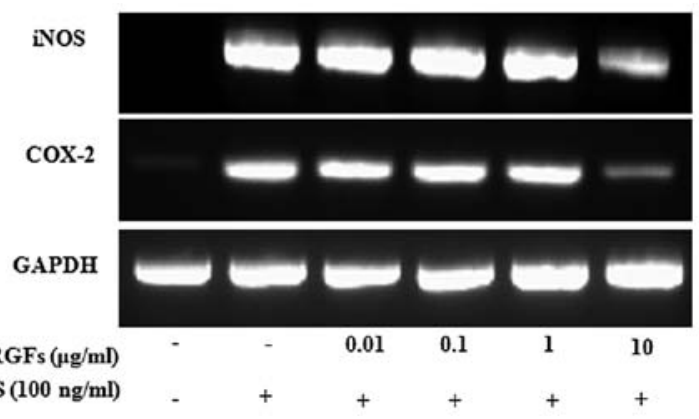

C

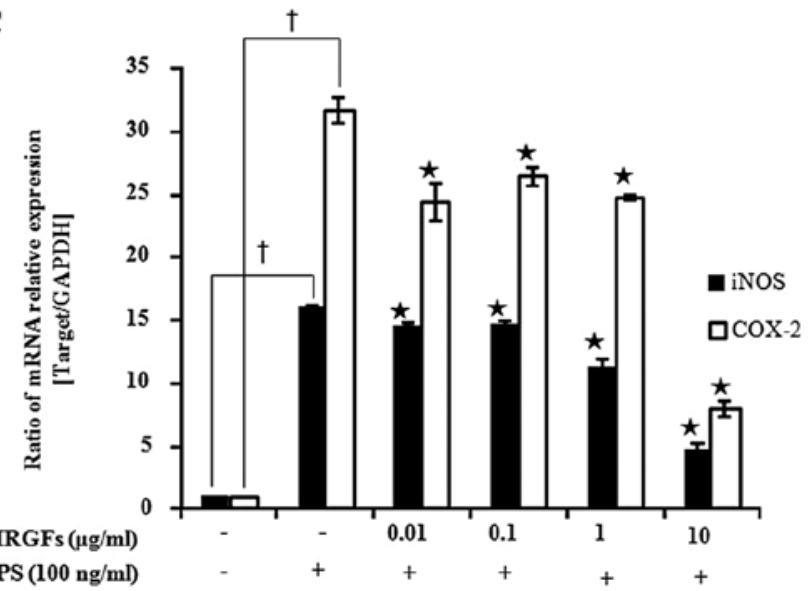

Figure 2. Effects of mixtures of recombinant growth factors (MRGFs) on the protein and mRNA expression of inducible nitric oxide synthase (iNOS) and cyclooxygenase-2 (COX-2) in RAW 264.7 cells stimulated with lipopolysaccharide (LPS). (A) RAW 264.7 cells were co-treated with various concentrations of MRGFs $(0,0.01,0.1,1$ and $10 \mu \mathrm{g} / \mathrm{ml})$ and LPS $(100 \mathrm{ng} / \mathrm{ml})$ for $24 \mathrm{~h}$. MRGFs, at $10 \mu \mathrm{g} / \mathrm{ml}$ inhibited the LPS-stimulated protein expression of iNOS and COX-2, as shown by in western blot analysis. (B and C) After the cells were co-treated with various concentrations of MRGFs $(0,0.01,0.1$, 1 and $10 \mu \mathrm{g} / \mathrm{ml})$ and LPS (100 $\mathrm{ng} / \mathrm{ml}$ ) for $6 \mathrm{~h}$, total RNA was extracted, and cDNA was synthesized for RT-PCR and real-time PCR. The results indicated that $10 \mu \mathrm{g} / \mathrm{ml}$ of MRGFs inhibited the LPS-stimulated mRNA expression of iNOS and COX-2. (C) Data are the means \pm standard deviation (SD) $(n=3)$. ${ }^{\dagger} \mathrm{P}<0.05$ vs. control; ${ }^{*} \mathrm{P}<0.05$ vs. LPS-stimulated mRNA expression.

phosphorylated levels of ERK. Compared with the control, the levels of phosphorylated ERK significantly increased after the cells were stimulated with LPS for $2 \mathrm{~h}$ (Fig. 3A). The cells were then co-treated with LPS $(100 \mathrm{ng} / \mathrm{ml})$ and MRGFs at a concentration of $0.01,0.1,1$ and $10 \mu \mathrm{g} / \mathrm{ml}$ for $2 \mathrm{~h}$. At the concentration of $10 \mu \mathrm{g} / \mathrm{ml}$, the MRGFs inhibited the phosphorylation of ERK, but not that of JNK and p38 in the LPS-stimulated RAW 264.7 cells (Fig. 3B). To confirm the causal link between the inhibition of the phosphorylation of MAPKs and MRGFs, the RAW 264.7 cells were pre-treated with ERK inhibitor (PD98059, $30 \mu \mathrm{M}$ )
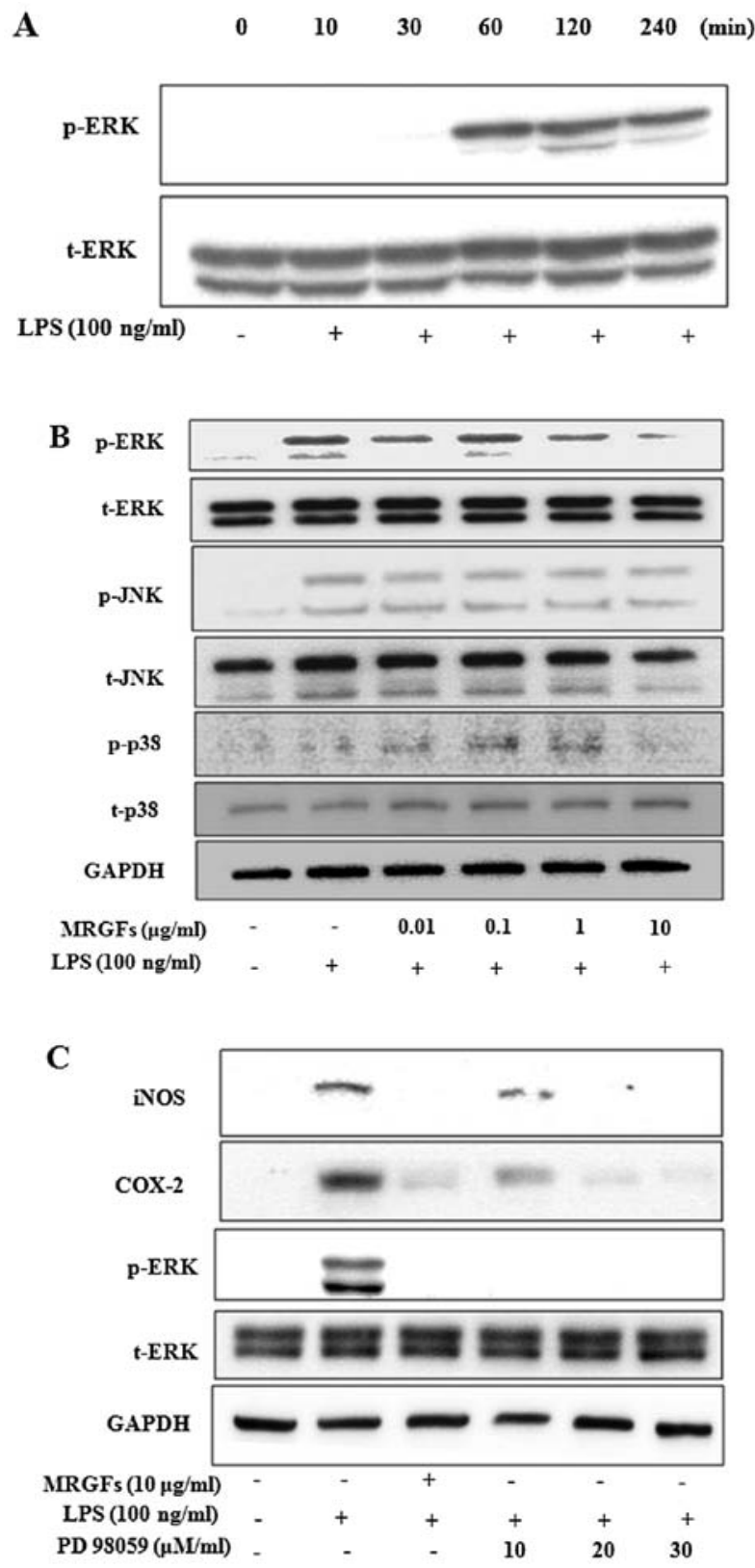

Figure 3. Effects of mixtures of recombinant growth factors (MRGFs) on the phosphorylation of mitogen-activated protein kinases (MAPKs) (A) RAW 264.7 cells were incubated with lipopolysaccharide (LPS) for the indicated time. LPS stimulation increased the phosphorylation of ERK at $2 \mathrm{~h}$ (B) RAW 264.7 cells were co-treated with various concentrations of MRGFs $(0,0.01,0.1,1$ and $10 \mu \mathrm{g} / \mathrm{ml})$ and LPS $(100 \mathrm{ng} / \mathrm{ml})$ for $2 \mathrm{~h}$. MRGFs, at $10 \mu \mathrm{g} / \mathrm{ml}$, inhibited LPS-stimulated ERK phosphorylation, as shown by western blot analysis. (C) After the RAW 264.7 cells were pre-treated with PD98059 (10, 20 or $30 \mu \mathrm{M} / \mathrm{ml})$ for $1 \mathrm{~h}$, they were co-treated with LPS $(100 \mathrm{ng} / \mathrm{ml})$ and MRGFs ( $10 \mu \mathrm{g} / \mathrm{ml})$ for $2 \mathrm{~h}$. Cell lysates were analyzed by western blot analysis using various antibodies against inducible nitric oxide synthase (iNOS) and cyclooxygenase-2 (COX-2). PD98059 (ERK inhibitor) inhibited the LPSinduced production of iNOS and COX-2 in a dose-dependent manner. The production of pro-inflammatory mediators, such as iNOS and COX-2, and ERK phosphorylation, which were induced by LFS were both inhibited by $30 \mu \mathrm{M} / \mathrm{ml}$ of PD98059 and $10 \mu \mathrm{g} / \mathrm{ml}$ of MRGFs.

for $1 \mathrm{~h}$. Following treatment with LPS $(100 \mathrm{ng} / \mathrm{ml})$ and MRGFs $(10 \mu \mathrm{g} / \mathrm{ml})$ for $2 \mathrm{~h}$, we confirmed that the production of LPS-stimulated pro-inflammatory mediators, such as iNOS and COX-2, as well as ERK phosphorylation were inhibited by $30 \mu \mathrm{M} / \mathrm{ml}$ of PD98059 and $10 \mu \mathrm{g} / \mathrm{ml}$ of MRGFs (Fig. 3C). 
Table I. Effect of MRGFs on pro-inflammatory cytokine production in LPS-stimulated RAW 264.7 cells.

Concentration $(\mu \mathrm{g} / \mathrm{ml})$ of MRGFs (administered with LPS)

Pro-inflammatory

mediator $(\mathrm{pg} / \mathrm{ml})$

Control LPS $100 \mathrm{ng}$

0.01

0.1

1

10

\begin{tabular}{lcccccc}
\hline IL-1 & $7.18 \pm 0.72$ & $71.88 \pm 3.29$ & $69.76 \pm 1.36$ & $67.43 \pm 3.18$ & $72.76 \pm 3.85$ & $62.23 \pm 12.81$ \\
IL-6 & $8.27 \pm 5.17$ & $1064.17 \pm 103.81$ & $1055.74 \pm 51.34$ & $1008.82 \pm 91.78$ & $983.42 \pm 57.75$ & $951.45 \pm 87.95$ \\
IL-10 & $46.32 \pm 5.24$ & $402.60 \pm 24.32$ & $381.04 \pm 24.64$ & $393.50 \pm 20.91$ & $309.34 \pm 7.04^{\mathrm{a}}$ & $284.58 \pm 11.80^{\mathrm{a}}$ \\
IL-12p40 & $102.65 \pm 7.20$ & $882.71 \pm 36.55$ & $932.01 \pm 132.61$ & $954.55 \pm 52.16$ & $765.64 \pm 125.92$ & $514.27 \pm 76.87^{\mathrm{a}}$ \\
GM-CSF & $295.91 \pm 27.69$ & $2007.73 \pm 100.71$ & $1858.30 \pm 96.60$ & $1836.32 \pm 128.42$ & $1500.67 \pm 461.97$ & $959.34 \pm 288.08^{\mathrm{a}}$ \\
MCP-1 & $1539.87 \pm 377.35$ & $3013.51 \pm 273.40$ & $3224.93 \pm 238.52$ & $2732.03 \pm 361.92$ & $2433.15 \pm 321.58$ & $2089.91 \pm 344.59^{\mathrm{a}}$ \\
TNF- $\alpha$ & $216.79 \pm 142.11$ & $1981.54 \pm 98.78$ & $1900.50 \pm 51.69$ & $1854.94 \pm 81.89$ & $1634.96 \pm 22.18^{\mathrm{a}}$ & $1128.78 \pm 46.50^{\mathrm{a}}$
\end{tabular}

The concentration of cytokines in the culture medium was measured after $24 \mathrm{~h}$ of incubation. Data are the means \pm SD ( $=3$ ). ${ }^{\text {a }}<0.05$ vs. LPSstimulated cytokine level. LPS, lipopolysaccharide; IL, interleukin; TNF- $\alpha$, tumor necrosis factor- $\alpha$.
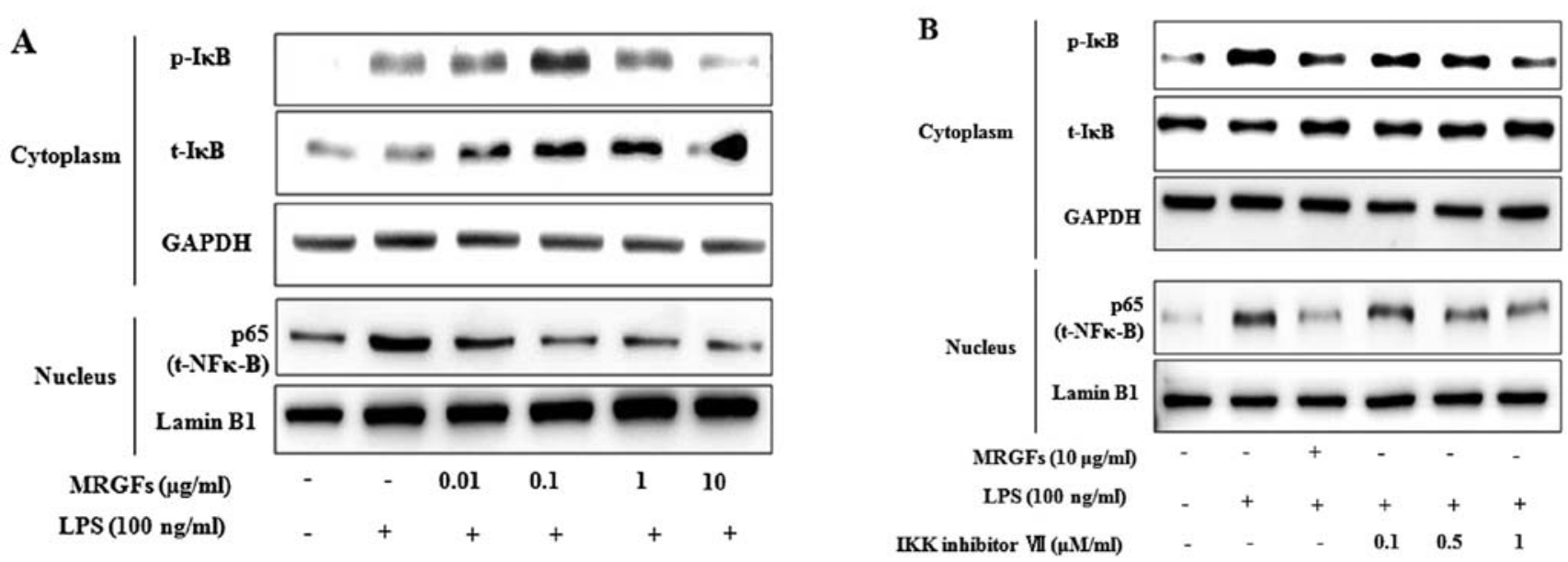

Figure 4. Effects of mixtures of recombinant growth factors (MRGFs) on lipopolysaccharide (LPS)-stimulated nuclear factor- $\mathrm{kB}$ (NF- $\mathrm{kB}$ ) activation, and inhibitory factor- $\mathrm{kB}$ (IאB) degradation and phosphorylation in RAW 264.7 cells. (A) After the RAW 264.7 cells were co-treated with MRGFs $(0,0.01,0.1,1$ and $10 \mu \mathrm{g} / \mathrm{ml})$ and LPS $(100 \mathrm{ng} / \mathrm{ml})$, the cells were incubated for $4 \mathrm{~h}$. Cytoplasmic and nuclear extracts of the cells were measured by western blot analysis. The results indicated

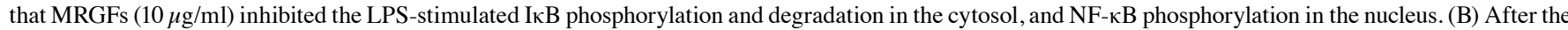
RAW 264.7 cells were pre-treated with IKK inhibitor VII $(0.1,0.5$ or $1 \mu \mathrm{M} / \mathrm{ml})$ for $2 \mathrm{~h}$, the cells were co-treated with MRGFs (10 $\mu \mathrm{g} / \mathrm{ml})$ and LPS (100 ng/ml) for

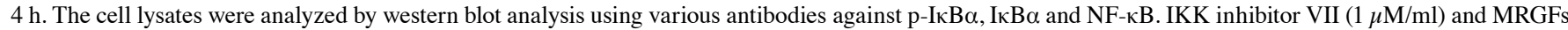

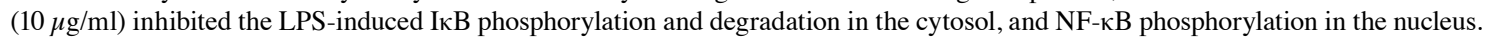

Inhibitory effects of MRGFs on $N F-\kappa B$ nuclear translocation, and $I \kappa B$ phosphorylation and degradation in LPS-stimulated RAW 264.7 cells. The cells were co-treated with LPS $(100 \mathrm{ng} / \mathrm{ml})$ and MRGFs at a concentration of $0.01,0.1,1$ and $10 \mu \mathrm{g} / \mathrm{ml}$ for $4 \mathrm{~h}$. The effects of MRGFs on NF- $\mathrm{B}$ nuclear translocation, and $\mathrm{I} \kappa \mathrm{B}$ phosphorylation and degradation in the cytoplasm and nucleus were then assessed by western blot analysis. Fig. 4A shows that the LPS-stimulated I $\mathrm{B}$ phosphorylation and degradation was significantly inhibited by MRGFs $(10 \mu \mathrm{g} / \mathrm{ml})$ in the cytoplasm of RAW 264.7 cells. Moreover, the amount of NF- $\kappa \mathrm{B}$ in the nucleus was markedly increased upon exposure to LPS alone, but MRGFs $(10 \mu \mathrm{g} / \mathrm{ml})$ inhibited the LPS-stimulated nuclear translocation of NF- $\kappa$ B. To confirm whether the MRGFs suppressed the activation of $\mathrm{NF}-\kappa \mathrm{B}$, the cells were pre-treated with the upstream inhibitor of NF- $\mathrm{B}$, IKK inhibitor VII, for $2 \mathrm{~h}$ and exposed to LPS (100 $\mathrm{ng} / \mathrm{ml})$ and MRGFs for $4 \mathrm{~h}$. We confirmed that the activation of the LPS-stimulated NF- $\kappa$ B pathway was inhibited by both $1 \mu \mathrm{M} / \mathrm{ml}$ of IKK inhibitor VII and $10 \mu \mathrm{g} / \mathrm{ml}$ of the MRGFs (Fig. 4B).

Inhibitory effects of MRGFs on inflammatory cytokine production in LPS-stimulated RAW 264.7 cells. Inflammatory cytokines, such as IL- $1 \beta$, IL- 6 and TNF- $\alpha$, were released as a result of the activation of the $N F-\kappa B$ pathway in the LPS-stimulated RAW 264.7 cells. We have already confirmed that MRGFs inhibit the activation of the NF- $\kappa \mathrm{B}$ pathway in the above-mentioned results. The effects of the MRGFs on the release of cytokines were assessed by ELISA. Table I shows the inhibitory effects of the MRGFs on the production of inflammatory cytokines (IL-1 $\beta$, IL-6, IL-10, IL-12p40, GM-CSF, MCP-I and TNF- $\alpha$ ) in the LPS-stimulated RAW 264.7 cells. Specifically, MRGFs, at a concentration of $10 \mu \mathrm{g} / \mathrm{ml}$, decreased the production of IL-10, IL-12p40, GM-CSF, MCP-I and TNF- $\alpha$ in the LPS-stimulated RAW 264.7 cells (Fig. 5). These 

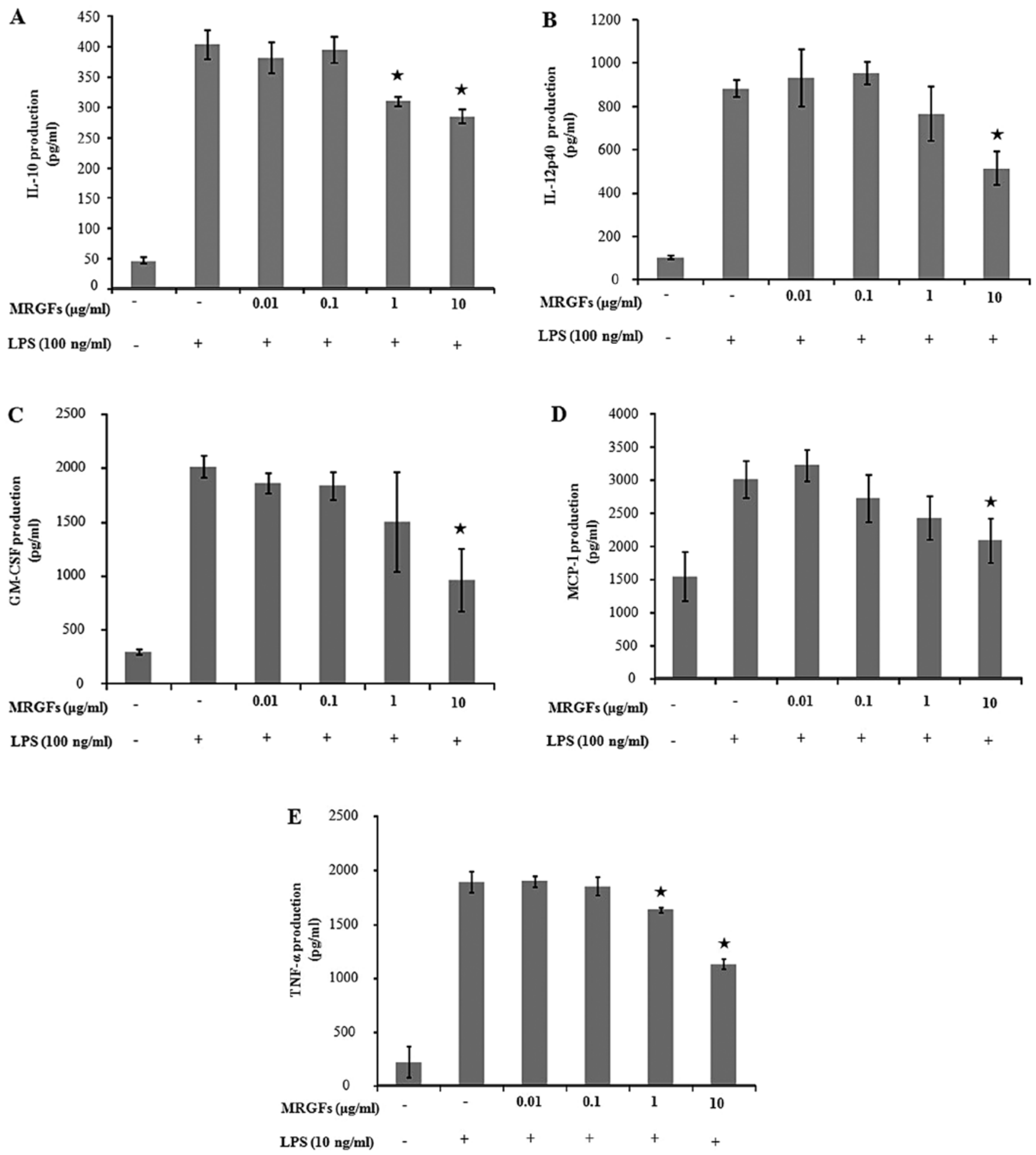

Figure 5. Effect of mixtures of recombinant growth factors (MRGFs) on cytokine production in lipopolysaccharide (LPS)-stimulated RAW 264.7 cells. RAW 264.7 cells were co-treated with various concentrations of MRGFs $(0,0.01,0.1,1$ and $10 \mu \mathrm{g} / \mathrm{ml})$ and LPS (100 ng/ml) for $24 \mathrm{~h}$. The cytokine concentration in the culture medium was determined using ELISA kits. Data are the means \pm standard deviation (SD) $(\mathrm{n}=3) .{ }^{*} \mathrm{P}<0.05$ vs. LPS-stimulated cytokine level.

results indicate that MRGFs can modulate the synthesis of several cytokines involved in the inflammatory process.

\section{Discussion}

The major finding of this study is that MRGFs play an important role in the LPS-stimulated inflammatory response. Previous studies (1-4) have demonstrated that various growth factors regulate a variety of cellular processes, such as cell growth, differentiation and proliferation, by binding to specific highaffinity cell membrane receptors. A number of studies have found a correlation between growth factors and wound healing, cancer and DNA synthesis in various cells $(13,16)$. Nonetheless, little information is available regarding the molecular mecha- 
nisms underlying the anti-inflammatory effects of various combinations of growth factors.

The activation of macrophages plays an important role in the initiation and propagation of inflammatory responses by inflammatory mediators (26). Therefore, LPS-stimulated macrophage activation increased the production of cytokines, such as IL-1 $\beta$, TNF- $\alpha$, GM-CSF and NO, which is modulated by the upregulation of iNOS (27). iNOS and COX-2 are often present together, share a number of similarities and play fundamental roles in similar pathophysiological conditions, such as inflammation and cancer $(28,29)$.

The MAPK and NF- $\mathrm{B}$ signaling pathways are important in the regulation of inflammatory mediators. Members of the MAPK family, including ERK, JNK and p38, are frequently involved in LPS-stimulated inflammation and play a critical role in the regulation of cell growth and differentiation, and in the control of cellular responses to cytokines and stresses.

The transcription factor, $\mathrm{NF}-\kappa \mathrm{B}$, controls a number of inflammatory mediators, such as iNOS, COX-2 and cytokines, and is important for immunity and inflammation (30). Previous studies have reported that the LPS-induced stimulation of $N F-\kappa B$ signaling activity leading to the activation of MAPK is a major mechanism underlying NO production by iNOS (31). When RAW 264.7 cells are stimulated by LPS, IкB is phosphorylated and separated from $N F-\kappa B$, resulting in the translocation of NF- $\kappa \mathrm{B}$ to the nucleus (32).

Cytokines can be used as markers of inflammation (33). The cytokines, TNF- $\alpha$ and IL-1 $\beta$, are closely related to each other and share many biological activities, i.e., pyrogenicity, activation of T lymphocytes, stimulation of fibroblast proliferation and neutrophil activation (34). IL-10 is a pleiotropic cytokine that modulates the adaptive immune-related cell function. It possesses immune stimulatory properties, including the ability to activate T cells, B cells, natural killer (NK) cells and mast cells $(35,36)$. In addition, previous studies have demonstrated that IL-6, MCP-1, GM-CSF and IL-12p40 are related inflammatory mediators (35). In particular, IL-12p40 has been reported to markedly upregulate the expression of TNF- $\alpha$ and induce the expression of iNOS in a dose-dependent manner (37).

In the present study, we treated LPS-stimulated RAW 264.7 cells with various concentrations of MRGFs. The aim was to elucidate the pharmacological, biological and inhibitory effects of MRGFs, which include EGF, bFGF, KGF, IGF-I and SOD, on the production of inflammatory mediators in macrophages. Our data clearly indicated that MRGFs suppressed the production of NO, iNOS and COX-2 in the LPS-stimulated RAW 264.7 cells. In addition, inhibiting the phosphorylation of ERK and $\mathrm{NF}-\kappa \mathrm{B}$ decreased the production of these inflammatory mediators. Furthermore, our data demonstrated that treatment with MRGFs decreased the production of inflammatory cytokines, such as IL-10, IL-12p40, GM-CSF, MCP-I and TNF- $\alpha$, in LPS-stimulated RAW 264.7 cells.

In conclusion, MRGFs have the potential to decrease the production of inflammatory mediators, such as iNOS, COX-2, IL-10, IL-12p40, GM-CSF, MCP-I and TNF- $\alpha$, by inhibiting the phosphorylation of the ERK and the activation of the NF- $\kappa \mathrm{B}$ signaling pathways. These findings suggest that MRGFs may prevent inflammatory diseases by suppressing MAPK- and $\mathrm{NF}-\kappa \mathrm{B}-\mathrm{mediated}$ inflammation.

\section{Acknowledgements}

This study was financially supported by the Ministry of Knowledge Economy (MKE) and the Korea Institute for Advancement of Technology (KIAT) through the Inter-ER Cooperation Projects.

\section{References}

1. Goustin AS, Leof EB, Shipley GD and Moses HL: Growth factors and cancer. Cancer Res 46: 1015-1029, 1986.

2. Childs CB, Proper JA, Tucker RF and Moses HL: Serum contains a platelet-derived transforming growth factor. Proc Natl Acad Sci USA 79: 5312-5316, 1982.

3. Taguchi M, Moran SL, Zobitz ME, et al: Wound-healing properties of transforming growth factor $\beta$ (TGF- $\beta$ ) inducible early gene 1 (TIEG1) knockout mice. J Musculoskelet Res 11: 63-69, 2008.

4. Hollwy RW and Kiernan JA: Control of the initiation of DNA synthesis in 3T3 cells: serum factors. Proc Natl Acad Sci USA 71: 2908-2911, 1974.

5. Martin P: Wound healing - aiming for perfect skin regeneration. Science 276: 75-81, 1997.

6. Matt P, Schoenhoff F, Habashi J, et al: Circulating transforming growth factor-beta in Marfan syndrome. Circulation 120: 526-532, 2009.

7. Kim HS: Assignment1 of the human basic fibroblast growth factor gene FGF 2 to chromosome 4 band $\mathrm{q} 26$ by radiation hybrid mapping. Cytogenet Cell Genet 83: 73, 1998.

8. Barrientos S, Stojadinovic O, Golinko MS, Brem $\mathrm{H}$ and Tomic-Canic M: Growth factors and cytokines in wound healing. Wound Repair Regen 16: 585-601, 2008.

9. Rotolo S, Ceccarelli S, Romano F, Frati L, Marchese C and Angeloni A: Silencing of keratinocyte growth factor receptor restores 5-fluorouracil and tamoxifen efficacy on responsive cancer cells. PLoS One 3: e2528, 2008.

10. Schultz G, Rotatori DS and Clark W: EGF and TGF-alpha in wound healing and repair. J Cell Biochem 45: 346-352, 1991.

11. Lee JA, Song HY, Ju SM, et al: Differential regulation of inducible nitric oxide synthase and cyclooxygenase-2 expression by superoxide dismutase in lipopolysaccharide stimulated RAW 264.7 cells. Exp Mol Med 41: 629-637, 2009.

12. Andres $\mathrm{C}$, Hasenauer J, Ahn HS, et al: Wound-healing growth factor, basic FGF, induces Erk1/2-dependent mechanical hyperalgesia. Pain 154: 2216-2226, 2013.

13. Weston CR, Lambright DG and Davis RJ: Signal transduction. MAP kinase signaling specificity. Science 296: 2345-2347, 2002.

14. Su B and Karin M: Mitogen-activated protein kinase cascades and regulation of gene expression. Curr Opin Immunol 8: 402-411, 1996.

15. Herlaar E and Brown Z: p38 MAPK signalling cascades in inflammatory disease. Mol Med Today 5: 439-447, 1999.

16. Chan-Hui PY and Weaver R: Human mitogen-activated protein kinase kinase kinase mediates the stress-induced activation of mitogen-activated protein kinase cascades. Biochem J 336: 599-609, 1998

17. Carter AB, Knudtson KL, Monick MM and Hunninghake GW: The p38 mitogen-activated protein kinase is required for NF-kappaB-dependent gene expression. The role of TATA-binding protein (TBP). J Biol Chem 274: 30858-30863, 1999.

18. Pearson G, Robinson F, Beers Gibson T, et al: Mitogen-activated protein (MAP) kinase pathways: regulation and physiological functions. Endocr Rev 22: 153-183, 2001.

19. Francisco V, Costa G, Figueirinha A, et al: Anti-inflammatory activity of Cymbopogon citratus leaves infusion via proteasome and nuclear factor- $\mathrm{\kappa B}$ pathway inhibition: contribution of chlorogenic acid. J Ethnopharmacol 148: 126-134, 2013.

20. Kim HG, Shrestha B, Lim SY, et al: Cordycepin inhibits lipopolysaccharide-induced inflammation by the suppression of NF-kappaB through Akt and p38 inhibition in RAW 264.7 macrophage cells. Eur J Pharmacol 545: 192-199, 2006.

21. O'Connor JC, McCusker RH, Strle K, Johnson RW, Dantzer R and Kelley KW: Regulation of IGF-I function by proinflammatory cytokines: at the interface of immunology and endocrinology. Cell Immunol 252: 91-110, 2008 
22. Twentyman PR and Luscombe M: A study of some variables in a tetrazolium dye (MTT) based assay for cell growth and chemosensitivity. Br J Cancer 56: 279-285, 1987.

23. Reddy DB and Reddanna P: Chebulagic acid (CA) attenuates LPS-induced inflammation by suppressing NF-kappaB and MAPK activation in RAW 264.7 macrophages. Biochem Biophys Res Commun 381: 112-117, 2009.

24. Bradford MM: A rapid and sensitive method for the quantitation of microgram quantities of protein utilizing the principle of protein-dye binding. Anal Biochem 72: 248-254, 1976.

25. Jeong Y and Mangelsdorf DJ: Nuclear receptor regulation of stemness and stem cell differentiation. Exp Mol Med 41: 525-537, 2009.

26. Tilg H, Wilmer A, Vogel W, et al: Serum levels of cytokines in chronic liver diseases. Gastroenterology 103: 264-274, 1992.

27. ter Steege JC, van de Ven MW, Forget PP, Brouckaert P and Buurman WA: The role of endogenous IFN-gamma, TNF-alpha and IL-10 in LPS-induced nitric oxide release in a mouse model. Cytokine 10: 115-123, 1998.

28. Wu KK: Inducible cyclooxygenase and nitric oxide synthase. Adv Pharmacol 33: 179-207, 1995.

29. Albini A and Sporn MB: The tumour microenvironment as a target for chemoprevention. Nat Rev Cancer 7: 139-147, 2007.

30. Barnes PJ and Karin M: Nuclear factor-kappaB: a pivotal transcription factor in chronic inflammatory diseases. N Eng J Med 336: 1066-1071, 1997.
31. Kim SH, Park HS, Lee MS, et al: Vitisin A inhibits adipocyte differentiation through cell cycle arrest in 3T3-L1 cells. Biochem Biophys Res Commun 372: 108-113, 2008.

32. Kao SJ, Lei HC, Kuo CT, et al: Lipoteichoic acid induces nuclear factor-kappaB activation and nitric oxide synthase expression via phosphatidylinositol 3-kinase, Akt, and p38 MAPK in RAW 264.7 macrophages. Immunology 115: 366-374, 2005.

33. Heinrich PC, Castell JV and Andus T: Interleukin-6 and the acute phase response. Biochem J 265: 621-636, 1990.

34. Flamand L, Gosselin J, D'Addario M, et al: Human herpesvirus 6 induces interleukin-1 beta and tumor necrosis factor alpha, but not interleukin-6, in peripheral blood mononuclear cell cultures. J Virol 65: 5105-5110, 1991.

35. Yuk SS, Lim EM, Lee JY, et al: Antiinflammatory effects of Epimedium brevicornum water extract on lipopolysaccharide-activated RAW264.7 macrophages. Phytother Res 24 1781-1787, 2010.

36. Mocellin S, Marincola F, Rossi CR, Nitti D and Lise M: The multifaceted relationship between IL-10 and adaptive immunity: putting together the pieces of a puzzle. Cytokine Growth Factor Rev 15: 61-76, 2004.

37. Jana M, Dasgupta S, Saha RN, Liu X and Pahan K: Induction of tumor necrosis factor-alpha (TNF-alpha) by interleukin-12 p40 monomer and homodimer in microglia and macrophages. J Neurochem 86: 519-528, 2003 